(c) Group of authors, 2017

UDC 616-053.2/.5:616.15.34

DOI - https://doi.org/10.14300/mnnc.2017.12075

ISSN - 2073-8137

\title{
THE INTERCONNECTION ACID-BASE BLOOD BALANCE AND DYSBIOSIS IN CHILDREN WITH CHRONIC CONSTIPATION
}

\author{
Kirgizov I. V. ${ }^{1}$, Minaev S. V. ${ }^{2}$, Kachanov A. V. ${ }^{2}$ \\ ${ }^{1}$ Central Clinical Hospital of the Presidential Administration of the Russian Federation, \\ Moscow, Russian Federation \\ 2 Stavropol State Medical University, Russian Federation

\section{ИЗМЕНЕНИЯ КИСАОТНО-ОСНОВНОГО СОСТОЯНИЯ КРОВИ И МИКРОБИОЦЕНОЗА ТОАСТОЙ КИШКИ У АЕТЕЙ С ХРОНИЧЕСКИМ ТОАСТОКИШЕЧНЫМ СТАЗОМ}

\author{
И. В. Киргизов 1, С. В. Минаев ${ }^{2}$, А. В. Качанов ${ }^{2}$ \\ ${ }^{1}$ ЦКБ с поликАиникой Управления Аелами ПрезиАента Российской ФеАерации, \\ Москва, Российская ФеАерация \\ 2 Ставропольский госуАарственный меАицинский университет, Российская ФеАерация
}

Interconnection of correlations of the acid-base blood balance with dysbiosis in 121 children with chronic constipation was found in the study. Metabolic acidosis is revealed with a high lactate concentration, emaciation of the organism buffer systems on the lowering background of main blood electrolytes and dehydration. And in its turn it takes place on the marked translocation of the intestinal microflora. The largest changes in the acid-base balance can be considered as a factor of the critical conditions in case of decompensated form of chronic constipation in this group of patients. The exposed changes must be taken into account not only while carrying out the intensive therapy of the occurred complications, but in case of conducting of conservative methods of correction of the disease. The lactate level in the blood can serve as a criterion of the efficiency of the operation in children with chronic constipation. Also it can be testify to the development of critical conditions.

Keywords: chronic constipation, dysbiosis, acid-base blood balance, children

Проведённое исследование кислотно-основного состояния крови и микробиоценоза толстой кишки у 121 ребенка с различными клиническими формами хронического толстокишечного стаза свидетельствует о взаимосвязи D-лактат ацидоза и декомпенсированного метаболического ацидоза с выраженной транслокацией кишечной микрофлоры. Наиболее грубые изменения в кислотно-основном равновесии при декомпенсированной форме колостаза можно считать фактором риска развития критических состояний в данной группе больных. Выявленные изменения необходимо учитывать не только при проведении интенсивной терапии возникших осложнений, но и при проведении консервативных методов коррекции данного заболевания. При этом уровень лактата крови у больных с хроническим толстокишечным стазом может служить как критерием эффективности проводимой терапии, так и показателем риска развития критических состояний.

Ключевые слова: хронический толстокишечный стаз, дисбиоз, кислотно-основное состояние крови, дети

C hronic constipation in childhood is a serious and an unsolved problem $[3,4,11]$. The functional infringements of the colon motor action are revealed after the first year of life, gradually, during several years, constipations assume a steady character. According to the literature data, critical conditions often appear and they lead to the lethal result, even in case of using modern intensive therapy strategies $[5,8]$. At the same time the depth of acidbase changes and the increase of a blood lactate level correlate with the heaviness of the disease, shock development and organ system insufficiency causing lethality $[10,12]$. Thus J. Aduen and coauthors (1994) proved that at the lactate increase to $2.7 \mathrm{mmol} / \mathrm{L}$ the vital functions infringements are not observed. But at achieving the level to $4.0 \mathrm{mmol} / \mathrm{L}$ the lethality reaches $50 \%$, at the increase to $6.0 \mathrm{mmol} / \mathrm{L}$ is $90 \%$. The other important factor in progressing of toxic complications development is the infringement of colon microbiocoenosis, colonic dysbiosis, supporting the hemostasis violation not only in the colon, but in the whole organism. Thus the acid-base balance violation and colonic dysbiosis in children are an important section in pathogenesis of chronic constipation and possible heavy complications.

The purpose of the research was to study the relationship between acid-base balance of blood and colonic dysbiosis in children with chronic constipation.

Material and Methods. The analysis of 121 tests of the vein blood was performed in patients from 1 to 14 years old with various forms of chronic constipation. The researches were conducted with a gas-analyzer «ABL-700» Radiometer (Denmark) with the estimation of the following indices: blood $\mathrm{pH}$, base actual abundance (BE), blood bicarbonate concentration ( $\mathrm{HCO} 3)$, lactate, anion difference, hematocrit and main electrolytes (sodium, potassium, chlorium), oxygen saturation, partial oxygen pressure, carbonic acid gas. For the estimation of colonic dysbiosis we carried out the bacteriological faeces research in the first day of patient's admittance to hospital. The taken material of faeces in cultivation from $10^{-1}$ to $10^{-9}$ was sowed on the complex of the culture (Ploskireva, Endo, Levina, Blauroc, 
Saburo, yolk-salt agar, blood agar). The identification of the cultivated cultures was performed taking into account morpho-bacterial, cultural and biochemical properties according to Bergy`s. The amount of pathogenic microbes of the intestinal group, the general amount of intestinal bacillus with slightly marked fermentative properties, lactose negative enterobacteria, hemolysing intestinal bacillus, coccus forms, Proteus fungus, Candida fungus and opportunistic pathogen enterobacteria were reviewed. Taking into account the results of concrete bacteriological faeces investigation, evaluation of the colonic dysbiosis was fulfilled according to P. L. Sherbakov.

Fifty healthy children without operative treatment formed the control group. Numerical data were expressed as the mean \pm standard deviation. Student's $t$ test was used in the statistical analysis. A p value $<0.05$ was considered to indicate statistical significance. This study was conducted with the approval of the respective Institutional Review Boards.

Results and Discussion. In patients with the chronic form of constipation $(n=74)$ slight changes in acid-base blood balance we registered (Table 1): the blood value of $\mathrm{pH}$ was within the limits of 7.32-7.34 with a slight lowering of blood bicarbonates concentration to $21.2 \pm 0.9 \mathrm{mmol} / \mathrm{L}$, and the actual abundance (deficit) of bases changes insufficiently. The increase of anion difference appears to be about $15.7 \pm 1.1 \mathrm{mmol} / \mathrm{L}$ in comparison with the test group. The growth of lactate concentration is revealed to $2.1 \pm 0.1 \mathrm{mmol} / \mathrm{L}$. These indices testify that the fact that on the background of the non-volatile acids increase and as the consequence of the concentration decrease of one of the main buffers of the organism, blood $\mathrm{pH}$ remains within the norm. It means that compensated acidosis was observed. In this case a slight hyponatremia, hypopotassemia and hypochloremia with the indices of hematocrit are defined within the normal. The colonic dysbiosis violation research in the groups of patients (Table 2 ) revealed lowing by $25 \%$ of the total amount of the intestinal bacillus to $280.1 \pm 12.4 \mathrm{mln}$, $11.3 \pm 0.4 \%$ of them have weak fermentative activity. The change of other indices of the volume correlation of microbes in the faeces analysis reveals the increase of the pathogenic microorganisms number, that exceed insufficiently normal indices of the microbe spectrum of colon.

In case of the subcompensated form of the disease $(n=38)$ in acid-base state, more sufficient changes are revealed. Thus acidosis is defined with lowering of blood $\mathrm{pH}$ to 7.35 with more sufficient deficit of bases and lowering of blood bicarbonates concentration to $19.0 \pm 0.6 \mathrm{mmol} / \mathrm{L}$. The increase of anion difference to $18.5 \pm 0.8 \mathrm{mmol} / \mathrm{L}$ takes place on the background of the lactate increase to $3.2 \pm 0.3 \mathrm{mmol} / \mathrm{L}$. The hematocrit number increase to $42.0 \pm 1.2 \%$ is observed. In the gas composition of blood the partial oxygen pressure lowering is defined with its low saturation and the increase of the carbonic acid gas concentration. The electrolyte concentration in blood lows more sufficiently in comparison with the compensated form of the disease and the test group $\left(\mathrm{Na}^{+} 133.0 \pm 0.7 ; \mathrm{K}^{+} 3.35 \pm 0.05 ; \mathrm{Cl}^{-} 94.5 \pm 1.3\right)$. The defined changes of the acid-base balance and the electrolyte balance testify of the compensated mechanisms exhaustion on the background of the continuing increase of nonvolatile acids, and also the additional sequestration of liquid into the third space and as a consequence of the abovewritten the development of the subcompensated acidosis with dehydration phenomena. In patients of this group the colonic dysbiosis violations are defined by lowering of the total amount of the intestinal bacillus with the increase of bacillus content with weak fermentative activity to $52.1 \%$ against total amount. In case of the pathogenic microflora study, a considerable increase of the volume correlation draws attention. It differs in a rate from the indices of the test group. In this case the microorganisms are marked, which coagulate plasma (staphylococci, hemolysing intestinal bacillus, Candida fungus, etc.).

Table 1

The indices of acid-base blood balance

in patients with chronic constipation

\begin{tabular}{|c|c|c|c|c|c|}
\hline \multirow[b]{2}{*}{ № } & \multirow{2}{*}{$\begin{array}{c}\text { Indices } \\
\text { of acid-base } \\
\text { blood } \\
\text { balance }\end{array}$} & \multirow{2}{*}{$\begin{array}{c}\text { Control } \\
\text { group } \\
(\mathrm{n}=50)\end{array}$} & \multicolumn{3}{|c|}{ Forms of chronic constipation } \\
\hline & & & $\begin{array}{l}\text { Compen- } \\
\text { sated }\end{array}$ & $\begin{array}{l}\text { Subcom- } \\
\text { pensated }\end{array}$ & $\begin{array}{l}\text { Decom- } \\
\text { pensated }\end{array}$ \\
\hline 1 & $\begin{array}{l}\text { Bases } \\
\text { deficit }\end{array}$ & $\begin{array}{l}0 \pm \\
2.3\end{array}$ & $\begin{array}{c}-2.1 \pm \\
0.2\end{array}$ & $\begin{array}{c}-2.6 \pm \\
0.2\end{array}$ & $\begin{array}{l}-3.5 \pm \\
0.3^{*}\end{array}$ \\
\hline 2 & $\begin{array}{l}\text { Bicarbo- } \\
\text { nates (HCO3) }\end{array}$ & $\begin{array}{l}26 \pm \\
1.8\end{array}$ & $\begin{array}{c}21.2 \pm \\
0.9\end{array}$ & $\begin{array}{l}19 \pm \\
0.6^{*}\end{array}$ & $\begin{array}{c}17.1 \pm \\
0.7 *\end{array}$ \\
\hline 3 & $\begin{array}{l}\text { Hematocrit } \\
(\mathrm{g} / \mathrm{I})\end{array}$ & $\begin{array}{c}38.6 \pm \\
2.9\end{array}$ & $\begin{array}{c}40.0 \pm \\
0.8\end{array}$ & $\begin{array}{c}42.0 \pm \\
1.2\end{array}$ & $\begin{array}{c}45.0 \pm \\
1.1^{*}\end{array}$ \\
\hline 4 & $\mathrm{pH}$ & $7.38 \pm 0.04$ & $7.35 \pm 0.02$ & $7.28 \pm 0.03$ & $7.2 \pm 0.02 *$ \\
\hline 5 & $\begin{array}{l}\text { Partial ox- } \\
\text { ygen pres- } \\
\text { sure (mm } \\
\mathrm{Hg})\end{array}$ & $41.2 \pm 4.1$ & $32.1 \pm 1.8^{*}$ & $25.7 \pm 1.3^{*}$ & $22.5 \pm 0.9 *$ \\
\hline 6 & $\begin{array}{l}\text { Partial } \\
\text { carbonic } \\
\text { acid gas } \\
(\mathrm{mm} \mathrm{Hg})\end{array}$ & $\begin{array}{c}45.9 \pm \\
2.2\end{array}$ & $\begin{array}{c}49.0 \pm \\
1.2^{*}\end{array}$ & $\begin{array}{l}51.9 \pm \\
0.8^{*}\end{array}$ & $\begin{array}{l}67.5 \pm \\
2.3^{*}\end{array}$ \\
\hline 7 & $\begin{array}{l}\text { Saturation } \\
(\%)\end{array}$ & $\begin{array}{c}65 \pm \\
5.3 \\
\end{array}$ & $\begin{array}{l}55.1 \pm \\
2.1^{*}\end{array}$ & $\begin{array}{c}40.6 \pm \\
3.5^{*} \\
\end{array}$ & $\begin{array}{c}32.3 \pm \\
2.1^{*}\end{array}$ \\
\hline 8 & \begin{tabular}{|l|} 
Lactate \\
$(\mathrm{mmol} / \mathrm{l})$
\end{tabular} & $\begin{array}{l}1.4 \pm \\
0.4\end{array}$ & $\begin{array}{c}2.1 \pm \\
0.1 \\
\end{array}$ & $\begin{array}{l}3.2 \pm \\
0.3^{*} \\
\end{array}$ & $\begin{array}{l}4.5 \pm \\
0.5^{*} \\
\end{array}$ \\
\hline 9 & $\begin{array}{l}\text { Anion } \\
\text { difference } \\
\text { (mmol/I) }\end{array}$ & $\begin{array}{l}12 \pm \\
1.5\end{array}$ & $\begin{array}{l}15.7 \pm \\
1.1^{*}\end{array}$ & $\begin{array}{c}18.5 \pm \\
0.8^{*}\end{array}$ & $\begin{array}{l}21.7 \pm \\
1.3^{*}\end{array}$ \\
\hline 10 & $\begin{array}{l}\mathrm{K}^{+} \\
(\mathrm{mmol} / \mathrm{l})\end{array}$ & $\begin{array}{c}4.41 \pm \\
0.7\end{array}$ & $\begin{array}{c}3.55 \pm \\
0.1\end{array}$ & $\begin{array}{c}3.35 \pm \\
0.05\end{array}$ & $\begin{array}{l}2.9 \pm \\
0.2^{*}\end{array}$ \\
\hline 11 & $\begin{array}{l}\mathrm{Na}^{+} \\
(\mathrm{mmol} / \mathrm{l})\end{array}$ & $\begin{array}{c}138 \pm \\
2.1 \\
\end{array}$ & $\begin{array}{c}135 \pm \\
0.6\end{array}$ & $\begin{array}{l}133 \pm \\
0.7^{*} \\
\end{array}$ & $\begin{array}{l}130 \pm \\
1.3^{*} \\
\end{array}$ \\
\hline 12 & $\begin{array}{l}\text { Chlorium } \\
(\mathrm{mmol} / \mathrm{l})\end{array}$ & $\begin{array}{l}101.5 \pm \\
3.5\end{array}$ & $\begin{array}{l}98.1 \pm \\
1.2\end{array}$ & $\begin{array}{l}94.5 \pm \\
1.3^{*}\end{array}$ & $\begin{array}{l}91.2 \pm \\
0.9 *\end{array}$ \\
\hline
\end{tabular}

${ }^{*} p<0.05$ in comparison with control group.

Table 2

Indices of dysbiosis in patients with chronic constipation

\begin{tabular}{|c|c|c|c|c|c|}
\hline \multirow[b]{2}{*}{ № } & \multirow{2}{*}{$\begin{array}{c}\text { Indices } \\
\text { of dysbiosis } \\
\text { in colon }\end{array}$} & \multirow{2}{*}{$\begin{array}{c}\text { Control } \\
\text { group } \\
(\mathrm{n}=50)\end{array}$} & \multicolumn{3}{|c|}{ Forms of chronic constipation } \\
\hline & & & $\begin{array}{l}\text { Compen- } \\
\text { sated }\end{array}$ & $\begin{array}{l}\text { Subcom- } \\
\text { pensated }\end{array}$ & $\begin{array}{c}\text { Decom- } \\
\text { pensated }\end{array}$ \\
\hline 1 & $\begin{array}{l}\text { Total } \\
\text { amount } \\
\text { of intestinal } \\
\text { bacillus, } \\
\text { mln }\end{array}$ & $\begin{array}{c}350.2 \pm \\
20.8\end{array}$ & $\begin{array}{c}280.1 \pm \\
12.4^{*}\end{array}$ & $\begin{array}{c}150.2 \pm \\
10.2^{*}\end{array}$ & $\begin{array}{c}12.1 \pm \\
5.6^{*}\end{array}$ \\
\hline 2 & $\begin{array}{l}\text { Intestinal } \\
\text { bacillus with } \\
\text { a weakly } \\
\text { defined } \\
\text { fermentative } \\
\text { activity, \% }\end{array}$ & $\begin{array}{c}2.2 \pm \\
0.9\end{array}$ & $\begin{array}{c}11.3 \pm \\
0.4^{*}\end{array}$ & $\begin{array}{l}52.1 \pm \\
3.5^{*}\end{array}$ & $\begin{array}{c}78.3 \pm \\
2.1^{*}\end{array}$ \\
\hline 3 & $\begin{array}{l}\text { Lactos-neg- } \\
\text { ative en- } \\
\text { terobacil- } \\
\text { lus, \% }\end{array}$ & $\begin{array}{c}3.2 \pm \\
1.1\end{array}$ & $\begin{array}{c}10.3 \pm \\
1.2^{*}\end{array}$ & $\begin{array}{c}21.3 \pm \\
1.2^{*}\end{array}$ & $\begin{array}{c}30.1 \pm \\
4.1^{*}\end{array}$ \\
\hline 4 & $\begin{array}{l}\text { Hemolysing } \\
\text { intestine } \\
\text { bacillus, \% }\end{array}$ & $\begin{array}{c}1.2 \pm \\
0.3\end{array}$ & $\begin{array}{l}3.2 \pm \\
0.9^{*}\end{array}$ & $\begin{array}{l}20.1 \pm \\
0.61^{*}\end{array}$ & $\begin{array}{c}60.4 \pm \\
1.7^{*}\end{array}$ \\
\hline 5 & $\begin{array}{l}\text { Coccus } \\
\text { forms, \% }\end{array}$ & $\begin{array}{c}7.4 \pm \\
1.2\end{array}$ & $\begin{array}{c}18.3^{ \pm} \\
2.1^{*}\end{array}$ & $\begin{array}{c}41.1 \pm \\
2.3^{*}\end{array}$ & $\begin{array}{c}61.6 \pm \\
1.5^{*}\end{array}$ \\
\hline 6 & $\begin{array}{l}\text { Staphylo- } \\
\text { cocci }\end{array}$ & $\begin{array}{c}2.2 \pm \\
0.2 \times 10^{2}\end{array}$ & $\begin{array}{c}3.3 \pm \\
0.6 \times 10^{3} * \\
\end{array}$ & $\begin{array}{c}5.1 \pm \\
0.2 \times 10^{6 *} \\
\end{array}$ & $\begin{array}{c}15.3 \pm \\
0.6 \times 10^{8 *}\end{array}$ \\
\hline 7 & $\begin{array}{l}\text { Opportunis- } \\
\text { tic patho- } \\
\text { gen entero- } \\
\text { bacteria }\end{array}$ & $\begin{array}{c}4.6 \pm \\
0.1 \times 10^{2}\end{array}$ & $\begin{array}{c}5.4 \pm \\
1.5 \times 10^{3 *}\end{array}$ & $\begin{array}{c}17.1 \pm \\
2 . \times 10^{6 *}\end{array}$ & $\begin{array}{c}19.1 \pm \\
2.5 \times 10^{8 *}\end{array}$ \\
\hline 8 & $\begin{array}{l}\text { Candida } \\
\text { fungi }\end{array}$ & $\begin{array}{c}7.2 \pm \\
1.3 \times 10^{2}\end{array}$ & \begin{tabular}{|c|}
$10.1 \pm$ \\
$0.5 \times 10^{4 *}$ \\
\end{tabular} & $\begin{array}{c}0.9 \pm \\
1.1 \times 10^{6 *} \\
\end{array}$ & $\begin{array}{c}21.1 \pm \\
0.5 \times 10^{8 *} \\
\end{array}$ \\
\hline
\end{tabular}

${ }^{*} p<0.05$ in comparison with the control group. 
The changes of the acid-base balance in patients with the decompensated form of chronic constipation $(n=15)$ had more vivid character. In the test group a considerable acidosis was defined with the value of $\mathrm{pH}$ less than 7.2. The lowering concentration of the blood bicarbonate to $17.1 \pm 0.7 \mathrm{mmol} / \mathrm{L}$ is observed. The increase of the base deficit is more $-3.8 \mathrm{mmol} / \mathrm{L}$. The lactate concentration reaches $4.5 \pm 0.5 \mathrm{mmol} / \mathrm{L}$ at a considerable increase of the anion difference, which reaches $21.7 \pm 1.3 \mathrm{mmol} / \mathrm{L}$. In gas composition of blood a continuing oxygen partial pressure lowering is observed with its low saturation and the increase of carbonic acid gas concentration. The increasing dehydration with the hematocrit indices $45 \%$, hyponatremia $(130.0 \pm 1.3 \mathrm{mmol} / \mathrm{L})$, hypopotassemia $(2.9 \pm 0.2 \mathrm{mmol} / \mathrm{L})$, hypochloremia $(91.2 \pm 0.9 \mathrm{mmol} / \mathrm{L})$ draws attention. In case of the decompensated variant of the disease in patients, the most deep microecological background violation of colon, with vivid symptoms of the intestinal flora translocation was observed. In the first turn the maximum lowering of the total intestinal bacillus to $-12.1 \pm 5.6 \mathrm{mln}$ was defined. In this fact its main volume $(78.3 \pm 2.1 \%)$ is formed by the intestinal bacillus with the weakly marked fermentative activity. The volume of opportunistic pathogen microorganisms' representation increases. Thus the amount of the lactose negative enterobacteria is increased to $30.1 \pm 4.1 \%$, hemolysing intestinal bacillus to $60.4 \pm 1.7 \%$, coccus forms to $61.6 \pm 1.5 \%$. The absolute number of staphylococci is considerably increased, opportunistic pathogen enterobacteria $\left(19.1 \pm 2.5 \times 10^{8}\right)$ and Candida fungi $\left(21.1 \pm 0.5 \times 10^{8}\right)$. The investigation of the microecological background of colon in case of the decompensated

\section{References}

1. Athanasakos E. P., Kemal K. I., Malliwal R. S., Scott S. M., Williams N. S. [etal.] Clinical and psychosocial functioning in adolescents and young adults with anorectal malformations and chronic idiopathic constipation. Br. J. Surg. 2013;100(6):832-839. doi: 10.1002/bjs.9111

2. Choung R. S. Shah N D. Chitkara D.,Branda C. Megan E. [et al.] Direct medical costs of constipation from childhood to early adulthood: a population-based birth cohort study. J. Pediatr. Gastroenterol. Nutr. 2011;52:47-54. doi: 10.1097/MPG.0b013e3181e67058

3. Howarth L. J., Sullivan P. B. Management of chronic constipation in children. Paediatrics and Child. Health 2016;26(10):415-422. doi: 10.1016/j.paed.2016.06.007

4. Kiefte-de Jong J. C., Escher J. C., Arends L. R., Jaddoe V. W. V., Hofman A. [et al.] Infant nutritional factors and functional constipation in childhood: the generation R study. Am. J. Gastroenterol. 2010;105:940-945. doi: 10.1038/ajg.2010.96

5. Kirgizov I. V., Minaev S. V. The ultrasonic way of the intraoperative assess of the resection volume of colon in children with chronic constipation. Medical News of North Caucasus. 2014;9(2):125-128. doi: 10.14300/ mnnc.2014.09035

6. Kirgizov I. V., Minaev S. V., Gladkiy A. P., Shishkin I. A. Shahtarin A. V. [et al.] Multicenter research of persistent cloacal malformation surgery in children. Medical News of North Caucasus. 2014:9(4):295-299. doi: 10.14300/ mnnc.2014.09083

7. Levitt M. A., Peña A. Pediatric fecal incontinence: a surgeon's perspective. Pediatr. Rev. 2010;31:91-101. doi: 10.1542/pir.31-3-91

8. Minaev S. V., Kirgizov I. V., Gladkyy A., Shishkin I., Gerasimenko I. Outcome of Laparoscopic Treatment of Anorectal Malformations in Children. World J. Surg. 2017;41(2):625-629. doi: 10.1007/s00268-016-3699-3

9. Pacilli M., Pallot D., Andrews A., Downer A., Dale L. [et al.] Use of Peristeen transanal colonic irrigation for bowel management in children: A single-center experience. J. Pediatr. Surg. 2013;(49)2:269-272. doi: 10.1016/j.jpedsurg.2013.11.036 form of chronic constipation revealed increase of the microorganisms content, which have the symptoms of aggression. And the pathogenic microorganisms are propagating themselves multiply. The total amount of the intestinal bacillus is minimal, and they have mainly a weakly marked fermentative activity.

Thus in patients with chronic constipation, the sufficient changes in the hemostasis systems are defined. That is the acid-base balance and water-electrolyte balance violation. Metabolic acidosis is defined with a high lactate concentration, with the organism buffer systems exhaustion on the lowering background of the basic blood electrolytes and dehydration. The above-written takes place on the vivid intestinal microflora translocation. The deepest violations in the acid-base balance in case of the decompensated form of constipation can be regarded as a risk factor of the critical condition development in this group of patients. Thus in case of the appearance of complications leading to the D-lactate concentration growth as one of the main products of the bacteria activity, or in case of aggressive treatment measures the D-lactate acidosis development with hypercapnia and decompensated metabolic acidosis with a high anion difference take place.

Conclusions. Our experience has shown that results should be taken into account not only during the intensive therapy of the appeared complications but also during the conservative methods of chronic constipation correction. In this situation the blood lactate in patients with chronic constipation can serve as a criterion of the conducted therapy effectiveness and as a risk development index of critical conditions.

10. Peeters B., Benninga M. A., Hennekam R. C. Childhood constipation; an overview of genetic studies and associated syndromes. Best Pract. Res. Clin. Gastroenterol. 2011;25:73-88. doi: 10.1016/j.bpg.2010.12.005

11. Pijpers M. A., Bongers M. E., Benninga M. A., Berger M. Y. Functional constipation in children: a systematic review on prognosis and predictive factors. J. Pediatr. Gastroenterol. Nutr. 2010;50:256-268. doi: 10.1097/MPG.0b013e3181afcdc3

12. Russell K. W., Barnhart D. C., Zobell S., Scaife E. R. Rollins M. D. Effectiveness of an organized bowel management program in the management of severe chronic constipation in children. Journal of Pediatric Surgery. 2015;50(3):444-447. doi: 10.1016/j.jpedsurg.2014.08.006

13. Shaman R., Manjuri D. N. Constipation in children: novel insight into epidemiology, pathophysiology and management. J. Neurogastroenterol. Motil. 2011;17(1):3547. doi: 10.5056/jnm.2011.17.1.35

14. Sullivan P. B., Alder N., Shrestha B., Turton L., Lambert B. Effectiveness of using a behavioural intervention to improve dietary fibre intakes in children with constipation. J. Hum. Nutr. Diet. 2011;25:33-42. doi: 10.1111/j.1365277X.2011.01179.x

15. Tabbers M. M., Boluyt N., Berger M. Y., Benninga M. A Clinical practice. Eur. J. Pediatr. 2011:170 (8):955-63. doi: 10.1007/s00431-011-1515-5

16. Valitutti F., Rybak A., Saliakellis E., Lindley K., Pensabene L. [et al.] Colonic manometry parameters can predict the outcome of the surgical ostomy formation in children with intractable constipation. Digestive and Liver Disease. 2016;48:e254-e254. doi: 10.1016/j.dld.2016.08.035

17. Yamataka A., Goto S., Kato Y., Koga H., Lane G. [et al.] Fecal and urinary continence after scope-assisted anorectovaginoplasty for female anorectal malformation. Pediatric Surgery International 2012;28(9):907-912. doi: 10.1007/s00383-012-3141-3

18. Youssef N. N., Langseder A. L., Verga B. J. Chronic childhood constipation is associated with impaired quality of life: a case-controlled study. J. Pediatr. Gastroenterol. Nutr. 2005;41:56-60. 
About authors:

Kirgizov Igor Vitalevich, MD, PhD, Professor, Head Department of Pediatric Surgery; tel.: +79057720953; e-mail: drkirgizov@yandex.ru Minaev Sergey Viktorovich, MD, PhD, Professor, Head of Department of Pediatric Surgery with the course of additional vocational training; tel.: +79624507653; e-mail: sminaev@yandex.ru

Kachanov Aleksandr Vasilevich, MD, Assistant of Professor Department of Pediatric Surgery with the course of additional vocational training; tel.: +79283174974; e-mail: 89283174974@mail.ru

(C) Shapkina A. N., 2017

UDC 617.55-001.31

DOI - https://doi.org/10.14300/mnnc.2017.12072

ISSN - 2073-8137

\section{ORGAN-PRESERVING TRENDS IN THE TREATMENT OF BLUNT SPLENIC TRAUMA IN CHILDREN}

Shapkina A. N.

Institute of Surgery, Pacific State Medical University, Vladivostok, Russian Federation

\section{ОРГАНОСОХРАНЯЮЩИЕ ТЕНАЕНЦИИ В АЕЧЕНИИ АЕТЕЙ С ЗАКРЫТОЙ ТРАВМОЙ СЕАЕЗЕНКИ}

\section{А. Н. Шапкина}

\section{Институт хирургии, Тихоокеанский госуАарственный меАицинский университет, ВлаАивосток, Российская ФеАерация}

The results of conservative and operative treatment of 128 children with the blunt splenic trauma (BST) during last 21 years are presented. All patients have been examined and treated during the period from 1996 to 2016 in the Regional Children's Hospital, Vladivostok, Russia. This period was divided into stages depending on the beginning of use of various diagnostic methods and getting more experience in their use. In the absence of CT authors have developed the algorithm of tactics in BST, including ultrasonography (US) and laparoscopy (LS). The ratio of splenectomies was more than $20 \%$ initially and decreased to less level than $5 \%$ of all cases.

Keywords: blunt splenic trauma, children, conservative treatment

Представлен результат консервативного и оперативного лечения 128 детей с закрытой травмой селезенки (ЗТС) в течение последнего 21 года. Всем пациентам проведено обследование и лечение за период с 1996 по 2016 год в Краевой детской больнице №1 г. Владивостока, Россия. Этот период был разделен на этапы в зависимости от начала использования различных методов диагностики и приобретения опыта в их использовании. Был разработан алгоритм тактики при ЗТС в отсутствие возможности проведения компьютерной томографии (КТ), наличии только ультразвукового исследования (УЗИ) и лапароскопии (ЛС). Уровень спленэктомий достигал более 20 \% пациентов до разработки алгоритма и снизился до уровня менее 5 \% всех случаев ЗТС.

Ключевые слова: травма селезенки, дети, консервативное лечение

\footnotetext{
T
} he blunt abdominal traumas in children compose only $2-5 \%$ of all traumas, and among them the blunt splenic trauma (BST) is about $66.6-90 \%$. Splenectomy causes a number of the severe immune complications. The problem of the immune function of spleen was discovered by King and Schumacher [8] in 1952, who informed about 5 cases of death of children as a result of sepsis after splenectomy. Splenectomy is accompanied by number of postoperative complications, the most serious is postsplenectomy sepsis, and mortality in this case may be 50-90\%. The risk of development of the infection depends on age of the patient - the greatest risk is found in children till 2 years of age, the danger decreases by age, but never disappears completely $[6,16]$.

For the last 30 years there were no significant changes in at traumas of Gl or kidneys in children. But the treatment tactics at the BST has undergone cardinal changes; there was a tendency to avoid operations and use conservative methods. Ruptures in the case of BST seldom involve segment vessels, and at laparotomy the spontaneous arrest of bleeding is often observed. Conservative treatment includes a strict bed regimen, monitoring, nasogastric tube, the urine control, supporting of stable hemodynamics. The child stays 5-7 days in bed in ICU or surgical unit. In the presence of not-stable hemodynamics or symptoms of Gl injury, operative treatment is necessary. The percent of conservatively cured children also considerably increases if aid is provided by children's surgeons in specialized hospitals [2, 3, 9, 10].

For the decision of choice of method of treatment the most important is hemodynamics but the additional diagnostic methods are of great value too. Ultrasonography is noninvasive and informative method at BST and also at liver 